Dyah R. A. Daties, Memahami Third World Approaches.....................

Jurnal Sasi Vol.23 No.1 Bulan Januari - Juni 2017

\title{
MEMAHAMI THIRD WORLD APPROACHES TO INTERNATIONAL LAW ( TWAIL)
}

\author{
Oleh: Dyah R. A. Daties
}

\begin{abstract}
The development of international law can not be separated from the history of the world, but the development can not be separated also from the dark width with the outbreak of World War I and World War II. After the end of World War II, the beginning of a period of brightness which is a new stage for the development of society and international law. There are some new changes and developments but the situation does not reflect the world as a whole because of the polarization of the world or the international community at that time was divided into two. The second group, which is the former colony of the former, considers that international law is heavily dominated by European and American values, and in no way accommodates the values of local wisdom from the former colonies. Along with the development of contemporary international law, the "lawsuit" of former colonies that are usually also referred to as third world countries against the domination of European and American countries in international law is the reason for the birth of Third World Approaches to International Law. TWAIL exists to solve, appearing to show the material and ethical issues and difficulties facing the Third World.
\end{abstract}

\section{Keyword: TWAIL, Third World}

\section{A. PENDAHULUAN.}

Hukum internasional adalah "an art" (suatu seni), bentuknya sangat tergantung pada siapa yang membentuknya. Ia tidak kaku, namun luwes mengikuti perkembangan jaman, khususnya perkembangan tingkah laku para subyek hukumnya. ${ }^{1}$ Asal mula sistem hukum internasional dimulai dari periode kuno kaidah-kaidah perilaku yang mengatur relasi masyarakat secara timbal-balik pada waktu

1 Melda Kamil Ariadno, 2007, Hukum Internasional Hukum Yang Hidup, Diadit Media, Jakarta, hal. 175. itu. Traktat-traktat, adat istiadat, perundang-undangan mengenai perang, bahkan perlindungan dan kekebalan para perwakilan kerajaan (yang kini kita kenal sebagai keistimewaan dan kekebalan diplomatik) telah dipraktekkan beberapa abad sebelum lahirnya agama Kristen, misalnya di Mesir dan di India kuno. Sejarah juga mencatat beberapa penyelesaian kasus melalui jalur arbitase dan mediasi yang dipraktekkan pada masa Cina kuno dan pada permulaan perkembangan dunia Islam.

Embrio hukum internasional juga berkembang dalam periode negara-negara Yunani, yang oleh Vinogradoff dilukiskan 
sebagai hukum intermunicipal. ${ }^{2}$ Hukum intermunicipal ini terdiri atas kaidah-kaidah kebiasaan yang telah dikristalisasikan kedalam hukum yang berasal dari adat-istiadat (usages) yang telah lama berlaku serta ditaati oleh kota-kota yang ada di Yunani saat itu. Kaidah-kaidah mengenai tidak dapat diganggu-gugatnya kurir-kurir atau utusan dalam peperangan, perlunya pernyataan terlebih dahulu tentang perang serta status perbudakan tawanan-tawanan perang. Kaidah-kaidah ini tidak hanya diterapkan dalam hubungan kota-kota Yunani yang berdaulat ini inter se, akan tetapi juga diterapkan juga dalam hubungan dengan negara-negara tetangganya. ${ }^{3}$ Namun, dasar dari kaidah-kaidah tersebut adalah pengaruh agama yang sangat kuat, yang merupakan suatu karakteristik suatu jaman dimana pemisahan antara hukum, moral, keadilan dan agama tidak dibatasi secara tegas.

Saat periode kekuasaan Romawi juga muncul kaidah-kaidah yang mengatur relasi antara Romawi dan berbagai macam bangsa atau rakyat yang ada di dunia kuno ketika itu. Salah satu aspek penting dari kaidah-kaidah yang berasal dari Romawi ini adalah pengaruh agama dalam karakter hukumnya sudah sangat berkurang. Pada jaman kekuasaan Romawi juga dikenal konsep pemanfaatan laut yakni konsep "rest communis omnium" (hak bersama seluruh umat manusia). Menurut konsep ini penggunaan laut bebas atau terbuka bagi semua orang. Setelah keruntuhan imperium Roma, negara-negara kecil yang muncul di sekitar laut Tengah mulai mengklaim hak kewilayahan atas laut di sekitar pantai. Venetia misalnya mulai mengklaim sebagian besar dari laut Adriatik, Genoa melakukan hal yang sama atas laut Liguria, sementara Pisa yang juga negara kecil pecahan Imperium Romawi mengklaim dan

2 J.G. Starke, 2014, Pengantar Hukum Internasional, Sinar Grafika, Jakarta, hal. 9.

3 Ibid. melakukan tindakan-tindakan penguasaan atas laut Thyrenia. Klaim-klaim atas wilayah laut tersebut kemudian oleh dua ahli hukum abad pertengahan, Bartolus dan Baldus, meletakkannya sebagai dasar-dasar pembagian wilayah laut, yakni bagian laut yang berada di bawah kekuasaan kedaulatan negara pantai, dan wilayah laut yang berada di luar kedaulatan negara pantai. Dua konsep penguasaan atas laut yang dipraktekkan Romawi saat itu kemudian kita kenal sebagai prinsip laut teritorial dan laut lepas (laut bebas) sebagaimana diatur dalam Konvensi PBB Tentang Hukum Laut (UNCLOS) $1982 .{ }^{4}$

Namun sesungguhnya lahirnya hukum internasional merupakan akibat langsung dari bermunculannya negara-negara beradab dan merdeka pada abad kelima belas dan keenam belas di Eropa yang dikenal sebagai masa renaissance (masa pencerahan). Para ahli hukum pada abad ini telah mulai memperhitungkan evolusi suatu masyarakat negara-negara merdeka dan berdaulat dan memikirkan serta menulis tentang berbagai macam persoalan hukum bangsa-bangsa. Mereka menyadari perlunya serangkaian kaidah guna mengatur aspek-aspek tertentu pada hubungan antar negara-negara tersebut. Andaikata tidak terdapat kaidah-kaidah kebiasaan yang tetap, maka para ahli hukum ini wajib menemukan dan membuat prinsip-prinsip yang berlaku berdasarkan nalar dan analogi. Mereka tidak hanya mengambil prinsip-prinsip hukum Romawi untuk dijadikan pokok bahasan kegiatan studi Eropa sejak penghujung abad kesebelas, akan tetapi para ahli hukum ini pun telah menjelaskan preseden-preseden sejarah kuno, hukum kanonik (canon law), dan konsep semi-teologis serta hukum alam (law of nature) - suatu konsep yang sejak berabad-abad lamanya memberi pengaruh besar terhadap perkembangan hukum

\footnotetext{
4 Dyah R.A. Daties, Sejarah Perkembangan
} Hukum Laut, Materi Kuliah Hukum Laut. 
internasional. ${ }^{5}$ Salah satu ahli hukum dan diplomat Belanda saat itu, Grotius, berhasil membuat risalah yang sistematis mengenai hukum internasional dalam karangannya yang berjudul De Jure Belli ac Paris atau Hukum Perang dan Damai.

Timbulnya hukum internasional juga tidak dapat dilepaskan dari Perjanjian West Phalia yang merupakan tonggak sejarah mengakhiri perang tiga puluh tahun di Eropa, tetapi bagaimanapun juga, perjanjian ini telah menghasilkan dokumen-dokumen penting bagi sejarah umat manusia di muka bumi. Persatuan Eropa (European Unity) dapat dipandang sebagai cikal bakal dari perjanjian ini. Demikian pula halnya dengan terbentuknya asosiasi-asosiasi regional banyak mengacu pada Perjanjian West Phalia ini. Konklusi perdamaian yang merupakan titik puncak dan Perjanjian West Phalia telah membawa semangat kebersamaan pada umat manusia di muka bumi, khususnya semangat kebersamaan pada pilar-pilar kemanusiaan bahwa, perang, kedengkian, pembinasaan, pemerkosaan hak-hak asasi adalah perbuatan dosa yang tidak terampuni di muka bumi.

Sejarah dunia kemudian memasuki lembaran hitam dengan meletusnya Perang Dunia I (1914-1918). Perang Dunia I hampir saja memporak-porandakan tata kehidupan masyarakat internasional pada masa itu, padahal dasar-dasarnya dengan susah payah telah diletakkan selama berabad-abad sebelumnya. Setelah berakhirnya Perang Dunia I, satu modal utama yang masih melekat pada masyarakat Internasional (negara-negara) adalah adanya kesadaran, bahwa perang atau kekerasan bukanlah merupakan cara terbaik untuk menyelesaikan sengketa. Bahkan dengan belajar dari pengalaman-pengalaman sebelumnya, muncullah keinginan-keinginan untuk mencegah dan menghapuskan peperangan yang pada hakekatnya hanyalah sebagai sarana untuk menghancurkan

\footnotetext{
5 J.G. Starke., Op.cit., hal. 11.
}

eksistensi umat manusia, meskipun sebenarnya sudah ada prinsip-prinsip dan kaidah-kaidah hukum yang mengaturnya. Berdirinya Liga Bangsa-Bangsa (the League of Nations) pada tahun 1919 tak lama setelah berakhirnya Perang Dunia I, sebagai organisasi internasional yang bergerak dalam ruang lingkup dan tujuan global, yakni mewujudkan ketertiban, keamanan, dan perdamaian dunia, secara tersimpul dapat pula dipandang sebagai usaha-usaha untuk kembali mengatur masyarakat internasional berdasarkan pada prinsip-prinsip dan kaidah-kaidah hukum internasional. ${ }^{6}$

Liga Bangsa-Bangsa ternyata gagal mencapai tujuan pendiriannya yakni mencegah terjadinya perang dan mewujudkan ketertiban, keamanan dan perdamaian dunia. Perang Dunia II meletus pada tahun 1939 dan diperluas dengan. Perang Asia Timur Raya yang meletus ketika Jepang membom pangkalan Angkatan Laut Amerika Serikat, Pearl Harbour di Hawaii pada tanggal 7 Desember 1941, merupakan peristiwa yang kedua kalinya memporak-porandakan struktur masyarakat internasional yang sebenarnya sudah mulai mapan. Belajar dan pengalaman sebelumnya, maka segera setelah berakhirnya Perang Dunia II pada tahun 1945, dibentuklah Perserikatan Bangsa-Bangsa (the United Nations) yang secara resmi berdiri pada tanggal 24 Oktober 1945 yang maksud dan tujuannya tidak jauh berbeda dengan Liga Bangsa-Bangsa. ${ }^{7}$

Setelah berakhimya Perang Dunia II, mulailah timbul masa kecerahan yang merupakan tahap baru bagi perkembangan masyarakat dan hukum internasional. Dikatakan demikian, oleh karena terjadi beberapa perubahan dan perkembangan baru yang sangat berbeda dengan masa sebelumnya. Keadaan itu tidak

${ }^{6}$ S.M. Noor., 2012, Sejarah Hukum Internasional, http://www.negarahukum.com/hukum/sejarah-hukum -internasional.html., diakses pada 16 Juni 2017.

7 Ibid. 
mencerminkan dunia secara menyeluruh, sebab sudah secara umum diketahui, bahwa semenjak awal abad XVII hingga setelah berakhimya Perang Dunia II, sebagian besar bangsa-bangsa di dunia, terutama di benua Asia, Afrika, dan Pasifik, merupakan bangsa-bangsa terjajah. Dengan demikian, polarisasi dunia atau masyarakat internasional pada masa itu terbagi menjadi dua. Pertama, kelompok bangsa atau negara penjajah (kolonial), khususnya negara-negara di benua Eropa dan Amerika, yang merupakan bagian kecil dari bangsa-bangsa di dunia. Kedua, kelompok yang jumlahnya jauh lebih besar, yaitu bangsa-bangsa atau wilayah terjajah di benua Asia, Afrika, dan beberapa wilayah di kawasan Pasifik. ${ }^{8}$

Para ahli hukum internasional dari kelompok kedua yang merupakan negara-negara bekas jajahan kelompok pertama, menilai bahwa hukum internasional sangat di dominasi oleh nilai-nilai Eropa dan Amerika, dan sama sekali tidak mengakomodir nilai-nilai kearifan lokal dari negara-negara bekas jajahan tersebut. Seiring dengan berkembangnya hukum internasional kontemporer, "gugatan" negara-negara bekas jajahan yang biasanya juga disebut sebagai negara-negara dunia ketiga terhadap dominasi negara-negara Eropa dan Amerika dalam hukum internasional inilah yang menjadi alasan lahirnya TWAIL atau Third World Approches to International Law (Pendekatan-Pendekatan Dunia Ketiga Pada Hukum Internasional). Paper ini bertujuan untuk memberikan pemahaman tentang TWAIL.

\section{B. PEMBAHASAN}

"Mr. Chairman, I understand fully Sir Anthony Eden's remarks this morning about respect for the sanctity of international law. However Mr. Chairman, I should add one comment upon this, and that is that most of international treaties which are a reflection of international law do not respect the sanctity of men as equal human beings irrespective of their race, or their creed or locality. Most of the existing laws between Asian and African and the old-established western world are more or less outmoded and should be regarded as a burden of modern life. They should be revised and be made more adaptable to modern international relations and the emancipation of all parts of mankind". 9

(Pak Ketua, saya mengerti sepenuhnya ucapan Sir Anthony Eden pagi ini tentang penghormatan terhadap kesucian hukum internasional. Namun Pak Ketua, saya harus menambahkan satu komentar mengenai hal ini, bahwa sebagian besar perjanjian internasional, yang merupakan refleksi hukum internasional, tidak menghormati kesucian umat manusia sebagai mahkluk yang setara tanpa memandang ras mereka, atau kepercayaan atau wilayah dari mana mereka berasal. Sebagian besar hukum yang ada di antara Asia dan Afrika dan ada di dunia barat kuno telah ketinggalan jaman dan harus dianggap sebagai beban kehidupan modern. Mereka harus direvisi dan dibuat lebih mudah disesuaikan dengan hubungan internasional modern dan emansipasi seluruh bagian umat manusia).

Kata-kata diatas adalah penggalan pidato yang disampaikan oleh Roeslan Abdulgani sebagai pembelaan terhadap posisi Indonesia yang menarik diri sepihak dari Perjanjian Konferensi Meja Bundar 1949 yang dituduh sebagai pelanggaran pacta sunt servanda. Roeslan Abdulgani,

\footnotetext{
9 Pidato Menlu RI pada London Conference on Suez
} Canal, Aug. 16, 1956, in Abdulgani (note 25), 59. 
berpendapat bahwa tindakan itu bisa dibenarkan berdasarkan prinsip rebus sic stantibus. Presiden Soekarno juga menggunakan dalil yang diungkapkan oleh Roeslan Abdulgani diatas dalam setiap pidato retorikanya yang akhirnya berhasil menarik hati rankyat Indonesia untuk mendukung kebijakan anti terhadap hukum internasional. Soekarno mengkritik para ahli yang terlalu menekankan pada kesakralan perjanjian internasional karena setiap perjanjian harus dapat direvisi jika bertentangan dengan keadilan dan kemanusiaan. Menurut Soekarno, perjanjian internasional yang merestui penjajahan harus segera diakhiri. Pakar hukum lain yang mengecap pendidikan di Belanda, Muhammad Yamin, juga mengkritik hukum internasional yang berlaku saat itu sebagai ciptaan Eropa Barat dimana negara-negara Eropa Timur dan Asia tidak terlibat dalam permubataannya.

Sentimen anti hukum internasional ini telah mengkristal menjadi persepsi publik dan mengakibatkan perkembangan hukum internasional pada era ini di Indonesia sangat lambat bahkan mengarah ke apatisme. ${ }^{10}$

Sikap anti hukum internasional yang dianggap sebagai produk bangsa-bangsa penjajah yang berasal dari Eropa ternyata tidak saja ditunjukkan oleh Indonesia pada masa itu. Berakhirnya Perang Dunia II pada bulan Agustus 1945, tidak berarti berakhir pula situasi permusuhan di antara bangsa-bangsa di dunia dan tercipta perdamaian dan keamanan. Ternyata di beberapa pelosok dunia, terutama di belahan bumi Asia Afrika, masih ada masalah dan muncul masalah baru yang mengakibatkan permusuhan yang terus berlangsung, bahkan pada tingkat perang terbuka, seperti di Jazirah Korea, Indo Cina, Palestina, Afrika Selatan, Afrika Utara.

10 Damos Dumoli Agusman, 2014, Indonesia dan Hukum Internasional : Dinamika Posisi Indonesia Terhadap Hukum Internasional, Jurnal Opinio Juris Vol. 15 Januari - April 2014, hal. 20.
Masalah-masalah tersebut sebagian disebabkan oleh lahirnya dua blok kekuatan yang bertentangan secara ideologi maupun kepentingan, yaitu Blok Barat dan Blok Timur. Blok Barat dipimpin oleh Amerika Serikat dan Blok Timur dipimpin oleh Uni Sovyet. Tiap-tiap blok berusaha menarik negara-negara di Asia dan Afrika agar menjadi pendukung mereka. Hal ini mengakibatkan tetap hidupnya dan bahkan tumbuhnya suasana permusuhan yang terselubung di antara kedua blok itu dan pendukungnya. Suasana permusuhan tersebut dikenal dengan sebutan "perang dingin".

Timbulnya pergolakan dunia disebabkan pula oleh masih adanya penjajahan di bumi kita ini, terutama di belahan Asia dan Afrika. Memang sebelum tahun 1945, pada umumnya benua Asia dan Afrika merupakan daerah jajahan bangsa Barat dalam aneka bentuk. Tetapi sej ak tahun 1945, banyak daerah di Asia Afrika menjadi negara merdeka dan banyak pula yang masih berjuang bagi kemerdekaan negara dan bangsa mereka seperti Aljazair, Tunisia, dan Maroko di wilayah Afrika Utara; Vietnam di Indo Cina; dan di ujung selatan Afrika. Beberapa negara Asia Afrika yeng telah merdeka pun masih banyak yang menghadapi masalah-masalah sisa penjajahan seperti Indonesia tentang Irian Barat, India dan Pakistan tentang Kashmir, negara-negara Arab tentang Palestina. Sebagian bangsa Arab-Palestina terpaksa mengungsi, karena tanah air mereka diduduki secara paksa oleh pasukan Israel yang dibantu oleh Amerika Serikat.

Sementara itu bangsa-bangsa di dunia, terutama bangsa-bangsa Asia Afrika, sedang dilanda kekhawatiran akibat makin dikembangkannya pembuatan senjata nuklir yang bisa memusnahkan umat manusia. Situasi dalam negeri dibeberapa negara Asia Afrika yang telah merdeka pun masih terjadi konflik antar kelompok masyarakat sebagai akibat masa penjajahan (politik devide et impera) dan perang dingin antar blok dunia 
tersebut. Walaupun pada masa itu telah ada badan internasional yaitu Perserikatan Bangsa-Bangsa (PBB) yang berfungsi menangani masalah $\neg$ masalah dunia, namun nyatanya badan ini belum berhasil menyelesaikan persoalan tersebut. Sedangkan kenyataannya, akibat yang ditimbulkan oleh masalah-masalah ini, sebagaian besar diderita oleh bangsa-bangsa di Asia Afrika.

Keterangan Pemerintah Indonesia tentang politik luar negeri yang disampaikan oleh Perdana Menteri Mr. Ali Sastroamidjojo, di depan parlemen pada tanggal 25 Agustus 1953, menyatakan "Kerja sama dalam golongan negara-negara Asia Arab (Afrika) kami pandang penting benar, karena kami yakin, bahwa kerja sama erat antara negara-negara tersebut tentulah akan memperkuat usaha ke arah tercapainya perdamaian dunia yang kekal. Kerja sama antara negara-negara Asia Afrika tersebut adalah sesuai benar dengan aturan-aturan dalam PBB (Perserikatan Bangsa-Bangsa) yang menyenangi kerja sama kedaerahan (regional arrangements). Lain dari itu negara $\neg$ negara itu pada umumnya memang mempunyai pendirian-pendirian yang sama dalam beberapa soal di lapangan internasional, jadi mempunyai dasar sama (commonground) untuk mengadakan golongan yang khusus. Dari sebab itu kerja sama tersebut akan kami lanjutkan dan pererat".

Third World Approaches To International Law (TWAIL) terinspirasi oleh sejarah tersebut diatas. Konferensi Asia Afrika yang diselenggarakan di Bandung, Indonesia, tahun 1955 diakui sebagai tempat kelahiran TWAIL karena kala itu negara-negara Afrika dan Asia bersatu untuk menyelesaikan permasalahan Dunia Ketiga. TWAIL tampil untuk menunjukkan persoalan material dan etis serta kesulitan yang dihadapi Dunia Ketiga. TWAIL saat ini telah berkembang menjadi salah satu kajian dalam hukum internasional.

\section{PE N U T U P}

Setelah berakhimya Perang Dunia II, mulailah timbul masa kecerahan yang merupakan tahap baru bagi perkembangan masyarakat dan hukum internasional. Dikatakan demikian, oleh karena terjadi beberapa perubahan dan perkembangan baru yang sangat berbeda dengan masa sebelumnya. Keadaan itu tidak mencerminkan dunia secara menyeluruh, sebab sudah secara umum diketahui, bahwa semenjak awal abad XVII hingga setelah berakhimya Perang Dunia II, sebagian besar bangsa-bangsa di dunia, terutama di benua Asia, Afrika, dan Pasifik, merupakan bangsa-bangsa terjajah. Dengan demikian, polarisasi dunia atau masyarakat internasional pada masa itu terbagi menjadi dua. Kelompok kedua yang merupakan negara-negara bekas jajahan kelompok pertama, menilai bahwa hukum internasional sangat di dominasi oleh nilai-nilai Eropa dan Amerika, dan sama sekali tidak mengakomodir nilai-nilai kearifan lokal dari negara-negara bekas jajahan tersebut. Seiring dengan berkembangnya hukum internasional kontemporer, "gugatan" negara-negara bekas jajahan yang biasanya juga disebut sebagai negara-negara dunia ketiga terhadap dominasi negara-negara Eropa dan Amerika dalam hukum internasional inilah yang menjadi alasan lahirnya TWAIL atau Third World Approches to International Law. TWAIL terinspirasi oleh sejarah tersebut diatas. Konferensi Asia Afrika yang diselenggarakan di Bandung, Indonesia, tahun 1955 diakui sebagai tempat kelahiran TWAIL karena kala itu negara-negara Afrika dan Asia bersatu untuk menyelesaikan permasalahan Dunia Ketiga. TWAIL tampil untuk menunjukkan persoalan material dan etis serta kesulitan yang dihadapi Dunia Ketiga. TWAIL saat ini telah berkembang menjadi salah satu kajian dalam hukum internasional. 


\section{DAFTAR PUSTAKA}

Melda Kamil Ariadno, 2007, Hukum Internasional Hukum Yang Hidup, Diadit Media, Jakarta.

J.G. Starke, 2014, Pengantar Hukum Internasional, Sinar Grafika, Jakarta.

Dyah R.A. Daties, Sejarah Perkembangan Hukum Laut, Materi Kuliah
Hukum Laut.

S.M. Noor., 2012, Sejarah Hukum Internasional,

http://www.negarahukum.com/huk um/sejarah-hukum-internasional.h $\underline{\mathrm{tml}}$

Damos Dumoli Agusman, 2014, Indonesia dan Hukum Internasional : Dinamika Posisi Indonesia Terhadap Hukum Internasional, Jurnal Opinio Juris Vol. 15 Januari - April 2014 